\title{
CORPORATE GOVERNANCE: INDIAN PERSPECTIVE WITH RELATION TO SARBANES OXLEY ACT
}

\author{
Utkarsh Goel $^{1}$, Shailendra Kumar ${ }^{2}$, Kuldeep Singh $^{3}$ and Rishi Manrai ${ }^{4}$ \\ ${ }^{1,2,3}$ Department of Management Studies, Indian Institute of Information Technology Allahabad, India \\ ${ }^{4}$ Department of Management Studies, Symbiosis Centre for Management Studies, India \\ Abstract: Corporate governance is one of the most important legislative domains of a business \\ organization which has an impact on its profitability, growth and even sustainability of business. As \\ business circumstances are vary the investors are differ with respect to incentives, risk-attitude, and \\ different incentive strategies, the outcome of this process emerge as a kind of corporate governance \\ practices. In order to protect investors from financial irregularities, misleading and fraudulent \\ activities carried out by the firm the U.S Securities and Exchange Commission passed the act called \\ Sarbanes-Oxley Act (SOX), whereas in India the Clause 49 of SEBI, is many times termed as Indian \\ version of SOX but it has also been criticized for not being holistic in nature. Many of the corporate \\ governance regulations are scattered in various clauses of Indian Companies act too. In this paper we \\ aim to compare SOX and Indian regulations on corporate governance. We discuss the similarities, \\ differences, areas of SOX superiority and suggest various improvements which if incorporated in \\ Indian laws may lead to achievement of comprehensive regulation on corporate governance.
}

Keywords: Corporate Governance, Indian Clause 49, Sarbanes Oxley Act (SOX)

\section{Introduction: \\ Attention towards Corporate Governance}

In the corporate world, since frauds and scandals were arising, it can be seen that laws and rules come after when some of such frauds and scandals had already happened. How good is that? If we can predict the future frauds and scams and accordingly we can make certain laws and rules so that growing number of frauds could be minimized. From developed to developing countries, it can be seen that corporate frauds are a major problem which is increasing in its frequency as well as in its severity. In the era of globalization as new technologies are emerging the nature of business transactions are also changing. It became a challenging task for the organizations as business transactions became very complex (Rujitha T R, 2012). A corporation is a group of people which includes various stakeholders like employees, customers, investors, partners, government, and society. The relationship between managers and shareholders is fraught with conflicts due to the difference in their objectives, information asymmetry, and separation of ownership and control. Because of these conflicts, managers always have the ability to maximize their own benefits at the expense of shareholders. For mitigating these agency conflicts corporate governance structure evolves (Dey 2008). Corporate governance has received much attention in the corporate world after the high-profile scandals such as Adelphia, Enron, and WorldCom, were revealed in the United States (US) as well as Harshad Mehta, Ketan Parekh, Satyam, 2G were revealed in the Indian market. This lead to the most sweeping corporate governance regulation in the US named as Sarbanes-Oxley Act, (SOX) 2002 and in India it came in the form of Clause 49 of the Listing Agreement to the Indian stock exchange which comes into effect from 2005. The purpose was of ensuring the reduction in corporate frauds and irregularities. It recommended independent auditors and the financial heads to take the undertaking of the financial statements. Proponents of the rules argue that such rules are necessary because the corporate scandals indicate that existing monitoring mechanisms in the public corporations should be improved.

\section{Historical Perspective}

The term corporate governance was originally developed in 1962 which was a step for ensuring that shareholders who invest their money into the corporation receive a fair return on the investment made by them and also having 
a protection against those management activities which are unethical and also creates poor use of their invested money (Arsalidou and Wang, 2005). Over the past two centuries, there have been several critical events which occurred and make a drastic change in corporate governance.

Over the last several decades the US system of corporate governance structure has changed constantly. During the 1960s and 1970s, strong corporate managers and weak corporate owners can be seen. The resulting was seen as giving power to managers which called agency problem (Berle \& Means, 1932). Table 1 and Figure 1 shows the list of notable corporate frauds \& scams in the US while Table 2 and Figure 2 shows the list of notable corporate scams in India.

Table-1 Notable frauds \& scams in US

\begin{tabular}{|c|l|r|}
\hline Year & \multicolumn{1}{|c|}{ Scam } & Amount in INR \\
\hline 2001 & Enron & 4788.17 billion \\
\hline 2002 & WorldCom & 245.88 billion \\
\hline 2003 & HealthSouth & 90.59 billion \\
\hline 2004 & Adelphia Communications & 148.82 billion \\
\hline 2005 & American insurance Group & 252.35 billion \\
\hline 2008 & Madoff investment scandal & 1294.1 billion \\
\hline 2012 & JP Morgan & 388.23 billion \\
\hline
\end{tabular}

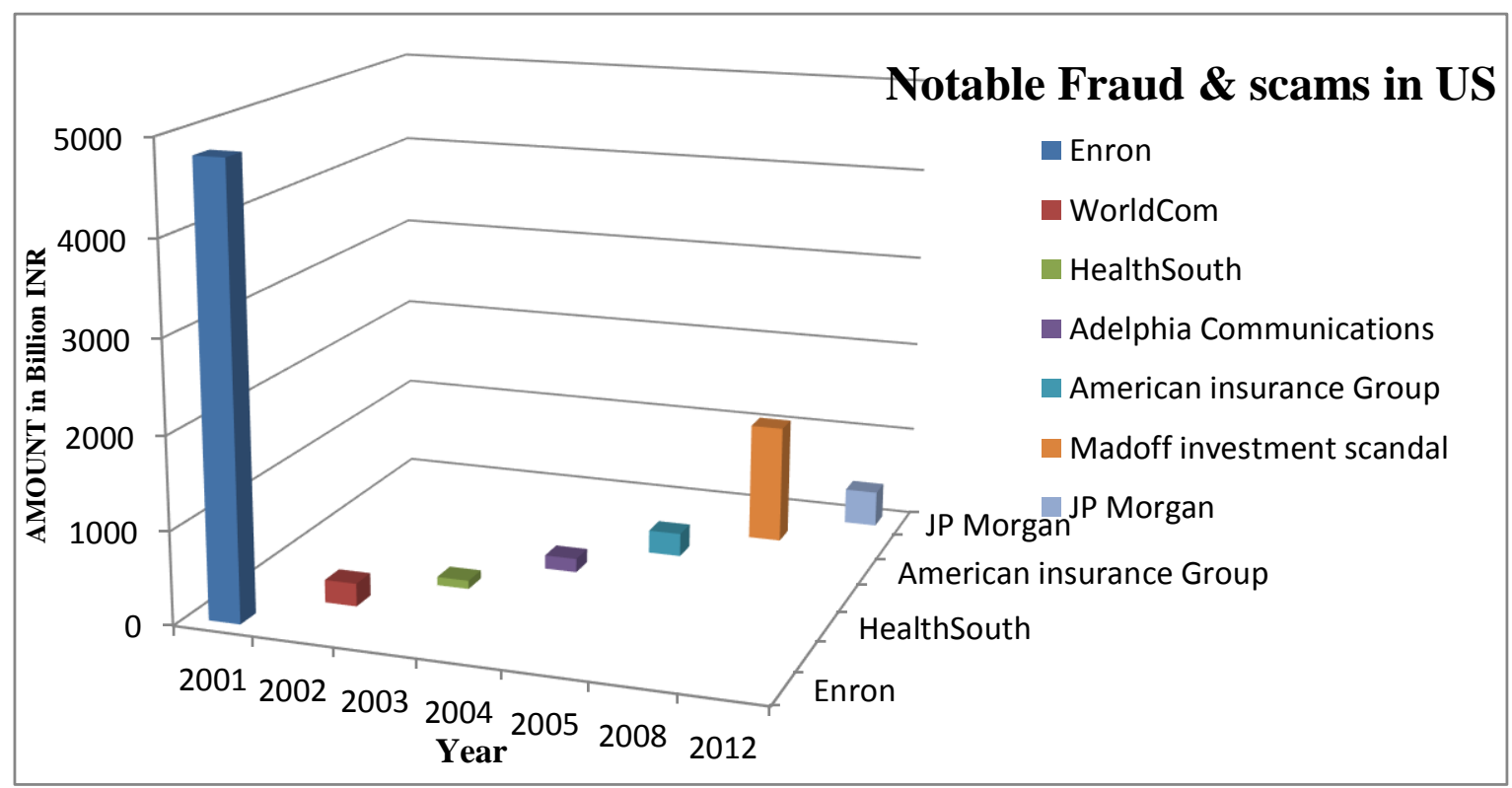

Figure 1 Notable Fraud and Scams in US

Before Enron, many key organizations in the US "model" of corporate governance were in place but the wave of speculation was also running parallel, due to which so many opportunities raised for short-term profit making through Initial Public Offering (IPO). 
Around the globe, a wide-ranging re-examination of corporate governance norms has been raised with the collapse of Enron in the year 2001 (Bratton, 2002, Coffee Jr., 2003). Enron revealed the fact that there were so many reasons due to which the system was not functioning as per the requirement. The weaknesses of each activity seemed to potentially undermine the other activity (Gordon, 2002). Again in 2002 WorldCom scandal creates focused substantial criticism on the US corporate governance. This lead to the emergence of SOX Act which was enacted by that time Republican Congress and President, generally SOX is seen as a piece of "progressive" regulation (Baker, 2008). From the above Table 1, it can be seen that after the emergence of SOX in the US the scandal rate was minimized but not comes to an end.

In India again there were some corporates which were indulged in speculation and short-term profit making through IPO. It was the year 1992 when the Harshad Mehta scam came into light as Mehta was dipping illegally into the stock manipulation activities financed by Worthless banks receipts.

Table-2 Notable frauds \& scams in India

\begin{tabular}{|r|l|r|}
\hline Year & \multicolumn{1}{|c|}{ Scam } & \multicolumn{1}{c|}{ Amount in INR } \\
\hline 1992 & Harshad Mehta securities scam & 50 billion \\
\hline 2001 & Ketan Parekh securities scam & 1.37 billion \\
\hline 2002 & Stamp paper scam & 200 billion \\
\hline 2008 & 2G scam & 1760 billion \\
\hline 2009 & Satyam Scam & 71.36 billion \\
\hline 2010 & Sahara Scam & 250 billion \\
\hline 2012 & Indian coal allocation scam & 1860 billion \\
\hline 2013 & Saradha Group financial scandal & 400 billion \\
\hline 2016 & Kingfisher Scam & 9 billion \\
\hline
\end{tabular}

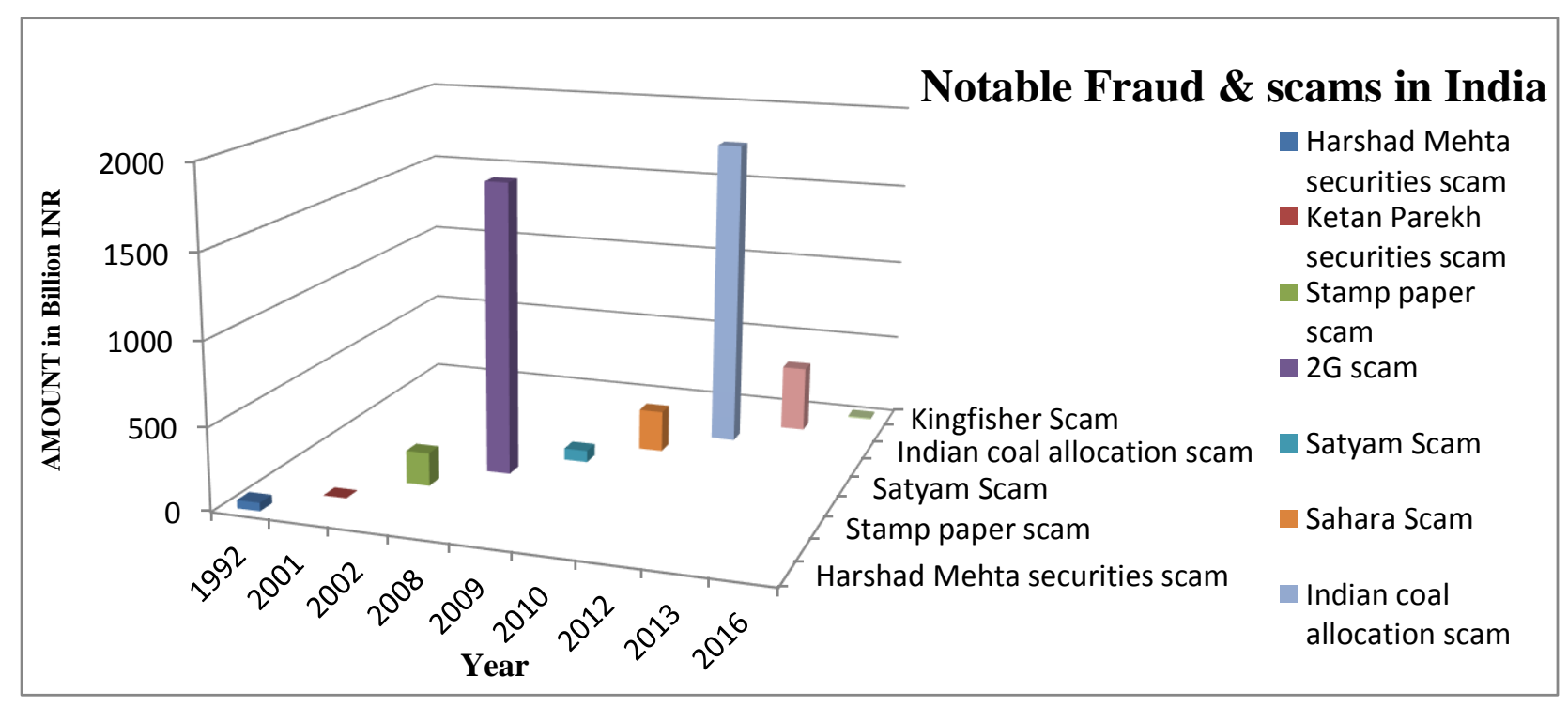

Figure 2 Notable Fraud and Scams in India

As Harshad Mehta considered "Sultan of Dalal Street", investors blindly followed his tricks. Harshad Mehta misused his status to manipulate the stock prices of particular shares on the stock for his personal financial gain. At that time Stock Exchange Board of India (SEBI) was not having such authority to regulate the transactions between investors and stockbrokers. The only authority which has the jurisdiction to look into the matter was the 


\section{Utkarsh Goel, Shailendra Kumar, Kuldeep Singh and Rishi Manrai/Corporate Governance: Indian \\ Perspective with Relation to Sarbanes Oxley Act}

Central Bureau of Investigation (CBI) (Nagarajan, G and Khaja Sheriff J, 2012). But In lieu of this, the Legislature system approved the SEBI Act, 1992. The SEBI Act provided SEBI 3 fold functions.

- Protection function- To protect the stock market activities from unscrupulous investors and to provide protection from unfair market practices.

- Development Function- To develop the stock market actively and lawfully.

- Regulation Function-: To regulate the transactions between stock brokers and investors.

In 1997, Mehta again tried to re-enter the markets by employed stock brokers who bought and sold shares at the stock market on his behalf for a commission. But at that time SEBI also had become too smart to catch the Harshad Mehta's tricks (Chandok S, 2015). During that period, SEBI had grown immensely and create a way to becoming the market watchdog. Resulting emergence of Clause 49 came into existence in late 2002. But as per Table 2, it can be seen that the corporate scams were still in continuation as Ketan Parekh scam revealed in 2001, the 2G scam in 2008, and Coal scam in 2013. It means SEBI was not successful in detecting the scam on its own; although it managed to lash back strongly to ensure such a scam never arise again.

\section{Corporate Fraud \& Reporting structure in India and US}

Corporate fraud is a worldwide scenario which affects all countries and all sectors of the economy. Corporate Fraud includes a wide-range of illegal acts and illegitimate practices involving misrepresentation, intentional deception. (Bhasin M. L., 2013).

The first initiative that US government has taken was the passing of Foreign Corrupt Practices Act in the year 1977 for ensuring sound corporate governance practices. It was mainly dealt with the systems of internal control. As high-profile failures were emerging the Treadway Commission was incorporated in the year 1985 which highlighting the necessary requirement for constituting Independent Boards and Committees. It was constituted for ensuring transparency with regard to the financial position of the company and other vital issues. In the year 2002 After Enron collapse, the US legislator enacted the SOX Act to protect investors from the possibility of fraudulent accounting activities by corporations. SOX mainly dealt with auditor's independence and financial disclosures.

When corporate governance practices were emerging around the world, India was lagging behind. In India, corporate governance gained prominence in the wake of liberalization during the 1990s. The reform of SEBI was the most significant initiative of 1992. At that time the main role of SEBI was to control and supervise the stock trading activities, with this SEBI also formed many corporate governance rules and regulations. After that it was also introduced as a voluntary measure by the Confederation of Indian Industry (CII) in 1996, at that time it created the set of laws which have rules and guidelines for Indian corporations as to initiate the act towards corporate governance. on May 7, 1999, two committees Narayan Murthy and Kumar Mangalam Birla was formed under Securities and Exchange Board of India in order to deal with insider trading and insider information, and also draft a code for best corporate governance practices. Based on the suggestions provided by these committees, Clause 49 was introduced so that the standards of Corporate Governance can be raised and promote. Timely it was reformed to incorporate and overcome the problems and contained all the regulations and requirement.

\section{Regulatory Legislations}

India has witnessed several corporate Frauds, few of them being can be seen above in Table-2. Indian Research evidence shows that growing number of corporate frauds and misleading activities have undermined the integrity of financial data, in results it contributed substantial economic losses, and investors also became eroded. The US has also witnessed several such corporate Frauds where fraudulent financial reporting and corrupt business practices having its existence since the era of footprints of the Public Corporation. 
A prior study of historical literature reveals that the state of non-compliance has typically been investigated using governance and financial variables (e.g., Kinney et al., 2004; Srinivasan, 2005, Abbott et al., 2004; Agrawal and Chadha, 2005; Beasley, 1996; Caruso, 2002; Erickson et al., 2006; Farber, 2005). However, it is generally accepted that the SOX Act of US and the Indian Clause 49 with equivalent Indian Regulations has improved the corporate governance compliances and decreased the incidence of misleading activities and fraud.

\section{US and India's Corporate Governance Norms- Comparative analysis of SOX and Clause 49 with equivalent Indian Regulations}

A comparative analysis has been made between the US and India to gain insights into the Corporate governance system in the both countries (Suraj A. B., Elango S., Pal S., et.al., 2012). The comparison will thus provide us with various factors on which the corporate governance of these can be distinguished and the factors on which they are similar

Table-3 Different Regulatory Legislation of India and US

\begin{tabular}{|l|l|l|}
\hline S. No. & \multicolumn{1}{|c|}{ India } & \multicolumn{1}{c|}{ US } \\
\hline 1 & $\begin{array}{l}\text { Indian Contract Act 1872, Clause 49 of Listing } \\
\text { Agreement }\end{array}$ & Sarbanes Oxley Act \\
\hline 2 & Indian Penal Code & Foreign Corrupt Practices Act \\
\hline 3 & Prevention of Corruption Act & Patriot Act \\
\hline 4 & Prevention of Money Laundering Act & OECD Guidelines \\
\hline 5 & The Companies Act 2013 & IIA Guidance \\
\hline
\end{tabular}

Table -4 Corporate Governance Regime in US and India

\begin{tabular}{|c|c|c|}
\hline Factors & Sarbanes-Oxley Act & $\begin{array}{l}\text { Clause } 49 \quad \& \quad \text { Equivalent Indian } \\
\text { Regulations }\end{array}$ \\
\hline Corporate governance structure & Rules based & Rules based \\
\hline Control & $\begin{array}{l}\text { In section } 404 \text { details regarding } \\
\text { control are specified }\end{array}$ & $\begin{array}{l}\text { Only specified but no elaborative } \\
\text { details are given }\end{array}$ \\
\hline Responsibility & $\begin{array}{l}\text { Board is responsible and accountable } \\
\text { for any frauds }\end{array}$ & $\begin{array}{l}\text { CEO and CFO are responsible and } \\
\text { accountable for any frauds }\end{array}$ \\
\hline Audit committee composition & Minimum of 3 independent directors & $2 / 3^{\text {rd }}$ independent directors \\
\hline $\begin{array}{l}\text { Review of internal control mech } \\
\text { by }\end{array}$ & $\begin{array}{l}\text { public company accounting } \\
\text { oversight board (PCAOB) }\end{array}$ & Audit committee \\
\hline Penalties and Punishments & $\begin{array}{l}\text { Penalties having range between loss } \\
\text { of stock from listing on the exchange } \\
\text { to fines upwards of millions of } \\
\text { dollars. } \\
\text { Provision for imprisonment can be } \\
\text { range from } 1 \text { year to } 25 \text { years }\end{array}$ & $\begin{array}{l}\text { Penalties having range between loss of } \\
\text { stock from listing on the exchange to } \\
\text { fines upwards of millions of dollars. } \\
\text { Provision for imprisonment can be } \\
\text { range from } 1 \text { month to } 10 \text { years }\end{array}$ \\
\hline Whistle blower protection & Strong protection laws in place & No strong protection laws in place \\
\hline
\end{tabular}

Although the intention of both the regulations is same, the structure and provision are much different.

$>\quad$ SOX provide a regulatory framework mainly for the internal control over the financial reporting ("ICFR"). Section 404(b) of SOX Act requires that an independent auditor attests to management's assessment of those 
internal controls. Financial information and accuracy which applied throughout the entire corporation should take into consideration as per all the controls which specified in the act. While on the other side the Clause 49 focuses on the guidelines related to corporate governance of the entire corporation. It means Clause 49 covers all the aspects related to the processes and not just financial process of the corporation.

$>\quad$ As per SOX, the boards are responsible for the internal control. They are certifying authority which is the principal financial official for the similar function. While Clause 49 has no any guidelines for boards as it mentioned the same for CEO and CFO of the business organization. CEO and CFO have to certify that the internal controls are in place. CEO and CFO are responsible if any frauds take place in the organization.

$>$ As per SOX, there would be a committee established by the board of directors of the issuer in order to oversee the financial reporting and accounting processes. If no committee is there then all directors who are on the board would be considered as a member of the audit committee. Each member who should be a director and also must be independent. As per Sarbanes-Oxley Act, the frequency related to audit committee meeting and the number of directors for constituting the audit committee is not specified. But in Clause 49,

1. There shall be minimum 3 directors as members in audit committee.

2. Independent directors shall be two-thirds of the members of the audit committee.

3. All members of the committee should be financially literate and at least single member shall have accounting and financial management experience.

The requirement for the independent director as to be a member of the audit committee is same for both the SOX and the Clause 49, but the information regarding the same is different in both the regulations. SOX tells regarding the independent person that any person who may not accept any consulting fee or compensation from the firm or affiliated to any subsidiary firm known as independent. Whereas in clause 49 , an independent director is any person who

- Takes only director's remuneration and not has any monetary benefits other than his remuneration.

- Does not have any relation with any other person who is holding the management position in the firm and also does not have any relation with the promoters of the firm.

- Has not been the executive in the immediate past 3 years and also not been a partner, in any legal and consulting firm of the organization or in any audit firm of the organization.

- Is not a service provider to the firm or supplier to the firm?

- Does not have more than two percent of the voting shares. As from above, we can see a clear meaning of the definition of the independent directors. In the Clause 49, the scope of exclusion of independent director is very much wider than the Sarbanes-Oxley Act.

$>$ The section 301 of SOX tells about the responsibilities of audit committee which includes retention and redressal of the complaints and establishing the procedures for receipt. The complaints can be related to auditing, accounting and internal controls of the firm. While on the other hand, under Clause 49 there is a disclosure section which said that Investors Grievance Committee shall be formed which include nonreceipt of declared dividends or balance sheet and the transfer of shares. Therefore, it can be observe that the SOX considers accounting related concerns very especially unlike clause 49.

$>$ As per SOX companies should reveal the accepted code of conduct and if there is no any accepted code of conduct then reasons should be given. However, in Clause 49 it is mentioned that it is necessary to publish the code of conduct on the company's website and it should be followed strictly by all the senior management staff and board members of the corporation. In the Indian framework code of conduct is mandatory for each firm. Also, the code of conduct is applicable to all the stakeholders, however, as per SOX, the code of conduct is applicable to the main financial officers only.

Legal Provisions for Penalties and Punishments in US: 
The SOX had a profound effect on corporate governance in the US. The SOX established stricter criminal penalties for securities fraud and changes how public accounting firms operate their businesses (Table-5).it imposes harsher punishment for obstructing justice, misleading or fraudulent financial reports, violations, mail frauds and wire frauds. The maximum punishment for securities frauds increased to twenty-five years, and the maximum imprison period for obstruction of justice increased to twenty years. The SOX also increased the penalties for public companies which are committing the same offense. Compliance penalties can be range from loss of exchange listing to fines upwards of millions of dollars.

Table -5 Legal Provisions for Penalties and Punishments in US (Source: US Sarbanes-Oxley Act, 2002)

\begin{tabular}{|c|c|c|}
\hline $\begin{array}{l}\text { Sarbanes-Oxley } \\
\text { Act of } 2002 .\end{array}$ & Related to & Penalties and Punishments \\
\hline Sec. 105 & $\begin{array}{l}\text { Investigations and disciplinary } \\
\text { proceedings. } \\
\text { If a firm has engaged in any act or } \\
\text { practice, or omitted to act, in } \\
\text { violation of this Act }\end{array}$ & $\begin{array}{l}\text { a monetary fine - (i) not exceed of } 1 \text { lakh US dollar } \\
\text { for a natural person or } 2 \text { million US dollar for any } \\
\text { other person; (ii) where paragraph } 5 \text { applies, it shall } \\
\text { not more than } 7.5 \text { lakh US dollar for a natural person } \\
\text { or } 15 \text { million US dollar for any other person }\end{array}$ \\
\hline Sec. 306 & $\begin{array}{l}\text { Insider trading throughout pension } \\
\text { fund blackout phases }\end{array}$ & $\begin{array}{l}\text { Fine up to } 100 \$ \text { for a day from the date of such failure } \\
\text { or as per section 101(i) denial to give notice to } \\
\text { applicants in accordance with the same }\end{array}$ \\
\hline Sec. 802 & $\begin{array}{l}\text { Criminal penalties for altering } \\
\text { documents }\end{array}$ & $\begin{array}{l}\text { shall be imposed fine under this head, imprisonment } \\
\text { for not more than } 20 \text { years, or both }\end{array}$ \\
\hline Sec. 807 & $\begin{array}{l}\text { Criminal penalties for defrauding } \\
\text { shareholders of publicly traded } \\
\text { companies }\end{array}$ & $\begin{array}{l}\text { shall be imposed fine under this head, imprisonment } \\
\text { for not more than } 25 \text { years, or both }\end{array}$ \\
\hline Sec. 903 & Mail Fraud and Wire Fraud & $\begin{array}{l}\text { (a) MAIL FRAUD.-Section } 1341 \text { of the title } 18 \text { - '5' } \\
\text { and inserting ' } 20 \text { '. } \\
\text { (b) WIRE FRAUD.-Section } 1343 \text { of title } 18 \text { - striking } \\
\text { ' } 5 \text { ' and inserting ' } 20 \text { ' }\end{array}$ \\
\hline Sec. 904 & $\begin{array}{l}\text { Violations related to the Employee } \\
\text { Retirement Income Security Act, } \\
\text { 1974. }\end{array}$ & $\begin{array}{l}\text { (1) striking } 5 \text { thousand US dollar and inserting } 1 \text { Lakh } \\
\text { US dollar (2) striking ' } 1 \text { year' and inserting ' } 10 \text { years'; } \\
\text { and (3) striking } 1 \text { lakh US dollar and inserting } 5 \text { Lakh } \\
\text { US dollar. }\end{array}$ \\
\hline Sec. 906 & $\begin{array}{l}\text { Penalties for certifying a } \\
\text { misleading or fraudulent financial } \\
\text { report }\end{array}$ & $\begin{array}{l}\text { Shall be imposed fine not more than } 1 \text { million } \$ \text { or } \\
\text { imprisoned not more than } 10 \text { years for knowing } \\
\text { violations and shall be fined not more than } 5 \text { million } \$ \\
\text { or imprisoned not more than } 20 \text { years for willful } \\
\text { violations. }\end{array}$ \\
\hline Sec. 1106 & $\begin{array}{l}\text { Increased crime related penalties } \\
\text { under Securities Exchange Act, } \\
1934\end{array}$ & $\begin{array}{l}\text { (1) Striking " } 1 \text { million } \$ \text {, or imprisonment for not } \\
\text { more than ten years" and inserting " } 5 \text { million } \$ \text {, or } \\
\text { imprisonment for not more than twenty years"; and } \\
\text { (2) striking " } 25 \text { million } \$ \text { " and inserting " } 25 \text { million } \\
\$ " \text {. }\end{array}$ \\
\hline
\end{tabular}





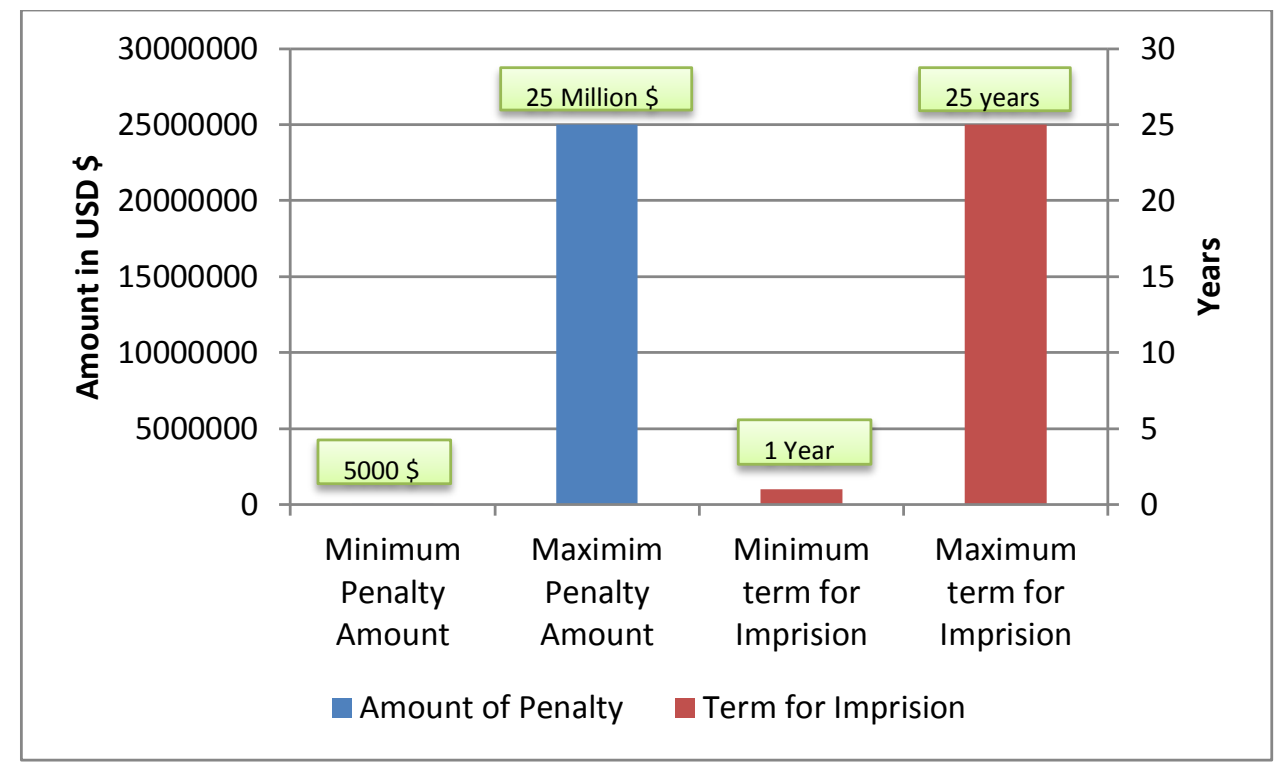

Figure 3 Legal Provisions for Penalties and Punishments in US

\section{Legal Provisions for Penalties and punishments in India as per Companies Act, 2013:}

The Indian Companies Act, 2013 also imposes stricter criminal penalties if specific violations including noncompliance made by directors and officers. This Act covers a wide range of violations made by any person either he belongs to officers or not. Under this new Act, there is also a provision for imprisonment along with penalties for any individual who found guilty for any kind of conduct which results into fraud under the Act. There is also provision for monetary penalties which arise in the case of failure to discharge duties as per under section 2(60). Apart from these general duties, statutory duties are also defined in the Companies Act, 2013 which related to statuary requirements fulfilled by the directors including the filing of personal details during incorporation, the disclosure of personal and professional interest, etc

. Table -6 Legal Provisions for Penalties and Punishments in India as per Companies Act, 2013 (Source: The Indian Companies Act, 2013)

\begin{tabular}{|c|c|c|}
\hline $\begin{array}{l}\text { Indian } \\
\text { companies Act, } \\
2013\end{array}$ & Related to & Penalties and Punishments \\
\hline Sec. 447 & Punishment for fraud & $\begin{array}{l}\text { Imprisonment of not less than six months and may } \\
\text { extend to ten years. Fine is not less than the amount } \\
\text { involved in and may extend to thrice the amount. If } \\
\text { the fraud involves public interest then the } \\
\text { imprisonment would not be less than three years. }\end{array}$ \\
\hline Sec. 448 & Punishment for false statement & The punishment is the same as applicable for fraud \\
\hline Sec. 449 & False proof & $\begin{array}{l}\text { There is a provision for a term Imprisonment which } \\
\text { will not be less than } 3 \text { years and can extend to } 7 \text { years } \\
\text { and with fine which can increase to rupees } 10 \text { lakh. }\end{array}$ \\
\hline Sec. 450 & $\begin{array}{l}\text { If there is no any provision for } \\
\text { penalty }\end{array}$ & $\begin{array}{l}\text { Monetary penalty of } 10 \text { thousand rupees and if the } \\
\text { contravention is an ongoing offence, then further fine } \\
\text { extending to } 1 \text { thousand rupees for each day. }\end{array}$ \\
\hline Sec. 451 & Repetitive default & $\begin{array}{l}\text { Punishable for double the amount of penalty, with any } \\
\text { imprisonment for the same }\end{array}$ \\
\hline Sec. 452 & $\begin{array}{l}\text { Unlawfully withholding of } \\
\text { property }\end{array}$ & $\begin{array}{l}\text { Fine not less than } 1 \text { lakh rupees but it can extend to } 5 \\
\text { lakh rupees. There is a provision for imprisonment }\end{array}$ \\
\hline
\end{tabular}




\begin{tabular}{|l|l|l|}
\hline & & $\begin{array}{l}\text { which is 2 years and when Court may ordered } \\
\text { restoration of property and in default thereof, }\end{array}$ \\
\hline Sec. 453 & $\begin{array}{l}\text { Punishment for improper use of the } \\
\text { word "limited" or "private limited" }\end{array}$ & $\begin{array}{l}\text { Fine of not less than 500 rupees but it can extend to } \\
\text { 2000 rupees for each day during which the title or } \\
\text { name has been used }\end{array}$ \\
\hline
\end{tabular}

\section{Legal Provisions for Penalties and punishments in India as per Securities Contract Regulation Act (SCRA), 1956}

Along with the companies act, 2013, every listed company also must comply with the rules and provisions of SCRA, Act, 1956 and SEBI Act, with their regulations. These Acts contains provisions for non-compliance as per the seriousness of the crime, may be in form of delisting of the company, impose penalties, imprisonment etc. as specified in the Act. Penalties can be resulting in the range from loss of listing on the stock exchange to fines upwards of millions of rupees.

Table -7 Legal Provisions for Penalties and Punishments in India as per Securities Contract Regulation Act, 1956 (Source: Securities Contract Regulation Act, 1956)

\begin{tabular}{|c|c|c|}
\hline $\begin{array}{l}\text { Securities } \\
\text { Contract } \\
\text { Regulation Act, } \\
1956\end{array}$ & Related to & Penalties and Punishment \\
\hline Sec. 23A & $\begin{array}{l}\text { Penalty for not furnishing the } \\
\text { required information, return, etc. }\end{array}$ & $\begin{array}{l}\text { Fine of rupees } 1 \text { lakh for each day during which such } \\
\text { kind of failure continues or } 10 \text { million rupees, } \\
\text { whichever is less for each failure. }\end{array}$ \\
\hline Sec. 23B & $\begin{array}{l}\text { Any person who enter into an } \\
\text { contract with clients }\end{array}$ & Same as applicable for Sec. $23 \mathrm{~A}$ \\
\hline Sec. $23 \mathrm{C}$ & $\begin{array}{l}\text { Penalty for failure if redress } \\
\text { investors' grievances arise }\end{array}$ & Same as applicable for Sec. $23 \mathrm{~A}$ \\
\hline Sec. 23D & $\begin{array}{l}\text { Penalty for moneys of client or } \\
\text { clients and for failure to segregate } \\
\text { securities or }\end{array}$ & $\begin{array}{l}\text { Monetary fine which may not exceeding } 10 \text { million } \\
\text { rupees }\end{array}$ \\
\hline Sec. 23E & $\begin{array}{l}\text { Penalty for delisting conditions or } \\
\text { grounds and failure to comply with } \\
\text { provision of listing conditions. }\end{array}$ & $\begin{array}{l}\text { Monetary fine which may not exceeding } 250 \text { million } \\
\text { rupees }\end{array}$ \\
\hline Sec. $23 \mathrm{~F}$ & $\begin{array}{ll}\text { Excess dematerialization } & \text { or } \\
\text { delivery of unlisted securities } & \end{array}$ & $\begin{array}{l}\text { Monetary fine which may not exceeding } 250 \text { million } \\
\text { rupees }\end{array}$ \\
\hline Sec. 23G & $\begin{array}{l}\text { Failed to provide timely returns, } \\
\text { etc. }\end{array}$ & $\begin{array}{l}\text { Monetary fine which may not exceeding } 250 \text { million } \\
\text { rupees }\end{array}$ \\
\hline Sec. $23 \mathrm{H}$ & $\begin{array}{l}\text { Contravention where there is no } \\
\text { any provision for penalty }\end{array}$ & $\begin{array}{l}\text { Shall be liable to a penalty which may extend to } 10 \\
\text { million rupees. }\end{array}$ \\
\hline Sec. $23 \mathrm{M}$ & Offences & $\begin{array}{l}\text { 1. if any person breaches the provisions of this Act or } \\
\text { any instructions or guidelines, for which no } \\
\text { penalty is provided elsewhere in this Act, then } \\
\text { there will be disciplinary imprisonment for a } \\
\text { period which can be extended for up to } 10 \text { years, } \\
\text { or with monetary penalty, which can be extend to } \\
250 \text { million rupees or both. } \\
\text { 2. If any person who is not paying the penalty amount } \\
\text { levied by the adjudicating officer or not to follow } \\
\text { any directions or orders given by adjudicating } \\
\text { officer, then there will be a provision for }\end{array}$ \\
\hline
\end{tabular}




\begin{tabular}{|l|l|l|}
\hline & $\begin{array}{l}\text { imprisonment for a period which is not less than 1 } \\
\text { month but which can extend to 10 years, or with } \\
\text { monetary penalty, which may extend to } 250 \\
\text { million rupees, or both. }\end{array}$ \\
\hline
\end{tabular}

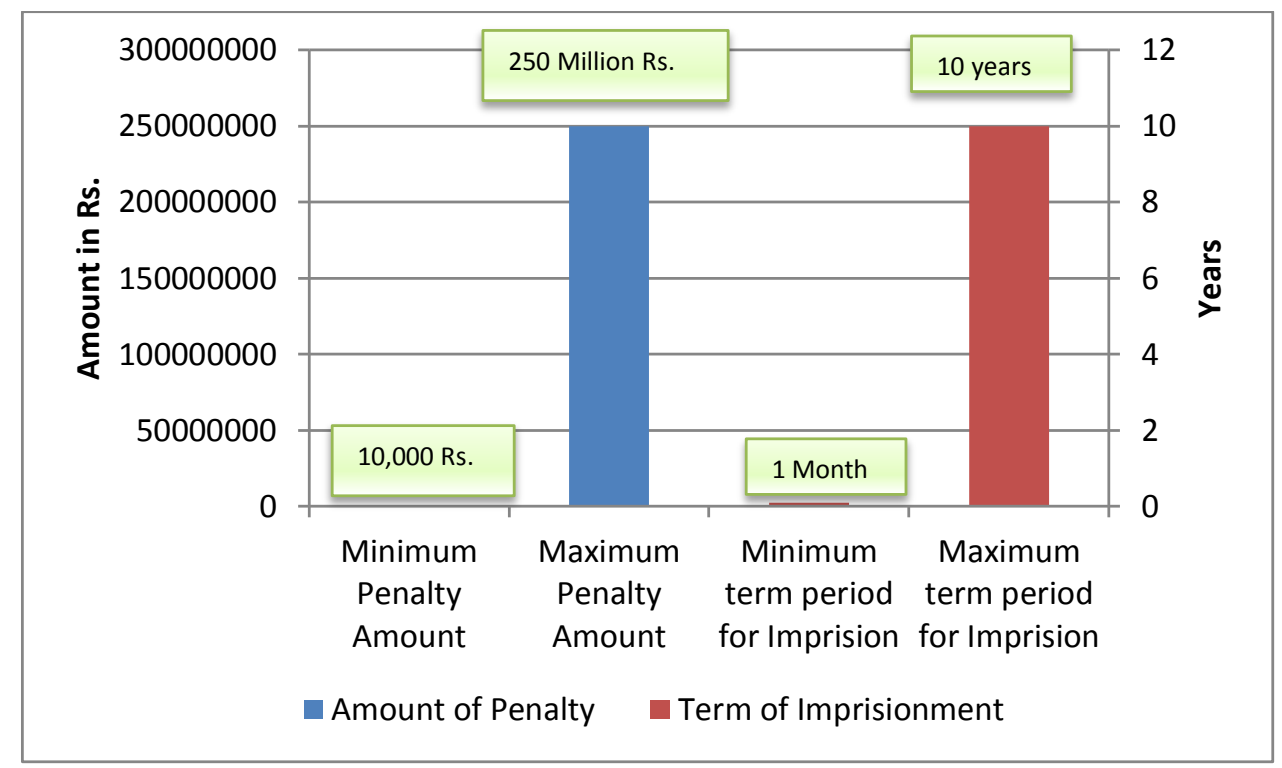

Figure 4 Legal Provisions for Penalties and punishments in India as per Companies Act, 2013 and Securities Contract Regulation Act, 1956

\section{Limitations in Corporate Governance Structure:}

From the above study, it seems that in both countries there is a proper structure of rules and regulation for corporate governance. But It is felt that rule-based approach alone may not serve the purpose of improving the Corporate Governance. As both countries said in their regulation to join a board as a nonexecutive director describing some directors as independent will create greater accountability upon them. It seems that they are independent and selected because of their skills, experience and not in conflict. But there are some issues related to independent directors which matter to co-operatives

$>$ There interests seems to be artificial

$>$ Tend to be more conservative

$>$ Spending other people's money

$>$ Moderator of independence for time service

Good corporate governance cannot be assured by independent directors but independence judgment can be a key considerable quality.

If there is any strict law or mandatory system, then again compliance is not certain as fear of penalties to be paid for non-compliance may not be influencing the firms. Many firms may simply ignore the rules and regulations and follow the non-compliance. If there is a well-performing firm with satisfied investors then corporate governance standards will be of secondary importance to them. In India, penalties are somewhere flexible since no criminal offense is implied by regulators, as companies of US under SOX which is more severe for noncompliance. As per Fig. 3 and 4 it can be seen that the provision for penalties and punishments are different in both country's regulations.

\section{Recommendation}


As in India the regulations are timely revised and amended but still, SEBI and Indian government is lacking to overcome the issues which are resulting in the form of noncompliance with corporate governance rules. Presently the Clause 49 and the Indian Companies Act 2013 is incorporating all the aspects of corporate governance. But as India is having the largest number of listed companies structure in the world, it is also needed to design and implement a dynamic mechanism of corporate governance legal structure, which protects the interests of investors and other stakeholders. The main additions which are required in the new legal structure are as follows:

$>$ Currently, in Indian corporate governance, there is no any Public Company Accounting Oversight Board (PCAOB) or similar kind of body which can deal with the audit process of the public listed companies. The Clause 49 which also comes under the purview and jurisdiction of SEBI not having any proper rules and guidelines related to auditing. In the year 2013 when the Indian Companies Act, 2013 came into existence which also supersedes the Clause 49 having some better rules and guidelines which can overcome the noncompliance of corporate governance. But still, there is a need of single entity like PCAOB in the Indian context. This is also required because we are having a comprehensive rulemaking body.

With the single entity rulemaking body for auditing, it should also be ensured that every auditor must follow the rules and guidelines completely.

The following responsibilities must be entrusted with rulemaking body:

- All the firms dealing accounting must be registered.

- Public company audits must perform with standards established for the purpose. Establishment of standards related to audits of public company.

- Required regulations and discipline must be enforced.

- Conduct inspections and disciplinary proceedings on regular basis for accounting firms.

$>$ As above already mentioned that the clause 49 and the Indian Companies Act 2013 did not mention any details related to internal controls. Therefore an amendment becomes necessary which should be made to create a benchmark with an internal control framework. Committee of Sponsoring (COSO) is also an Internal Control Framework adopted by US SOX Compliant companies. Such kind of adoption is necessary required for removing any ambiguity related to internal controls.

$>$ In a whole picture, India is not having such regulation which put strict control over white collar crimes. With the laws like Indian Companies Act, 2013, Cybercrime Act, Securities Contract Regulation Act, 1956, Indian Penal Code, etc. India is trying to address the white collar crimes in current times which are not sufficient enough. Corruption and non-compliance can only tackle and minimize with comprehensive legal bindings and punitive charges made along with.

The comprehensive legal structure must have featured in the lines of SOX, which is as follows:

- Imprisonment (which may vary between 1 to 25 years, as the case may be).

- The term of imprisonment must not be less than three years if litigation or fraud involves in the public interest.

- The monetary amount of fine must extend to three or four times of the amount of fraud committed in certain cases.

$>$ In the US the Statement on Auditing Standards (SAS) No. 70 is a standard which allows the auditors in order to assess the internal control. There are mainly two types of reports in the SAS 70 namely Type I and Type II. All the internal control framework design and domain of business entity are concerning with Type I, report and testing and evaluation of the effectiveness of controls implemented is concerned with Type II report. In Indian context a mandatory requirement of such type of auditing structure necessarily required.

This is also required because at present there is no any standard or regulation which provides any information for the assessment of internal controls. However, in Clause 49 somehow it is mentioned that internal controls 
should be in place. But, how it should implement, for that there is no any structural method. Therefore, as US is having the COSO for Internal Control framework, in India there is also a need for the same which will become mandatory to effectively check these internal controls. Such kind of organization will surely help the Directors, CEO/CFO so that they can certify the validity and operational effectiveness of the internal controls.

\section{Conclusion}

Acts like SOX, 2002 and Clause 49 of India which has more similar provisions of SOX has come forward in order to protect investors and other stakeholders of companies with some strong provisions. To keep a close vigil on corporate activities of companies such Acts have been passed and amended from time to time. Although Indian Corporate governance provisions discussed in Companies Act, 2013 is contained in several stringent features as compared to US SOX Act, but yet some provisions like PCAOB is still missing in Indian Clause 49. Oversight Boards under the SOX, has expressed with tremendous power of auditing, inspecting, investigating, and regulating the activities performed by auditors and auditing firms in U.S. Such powers also to be handed to Indian agencies of auditing, though The Institute of Chartered Accountants of India (ICAI), has vested with the task of auditing and inspecting the works of auditors and auditing agencies in India, but still ICAI has not empowered with making rules for ethical code of conduct for auditing works.

If talking about clarity of language or terms used in the Indian corporate governance provisions few terms like internal control is not defined clearly in any of the provisions whether it is Clause 49 or Companies Act, 2013. On the contrary, if SOX is considered for the definition of the same term i.e. internal control is planned to implement with a strongly recommended committee known as Committee of Sponsoring Organizations which is to be incorporated for the purpose of implementing internal control framework in companies. Incorporation of such a framework will certainly have a wide scope for clear explanation and understanding of the term internal control. Committee framework also has reliability factor attached with the structure of internal control among corporate entities. Ambiguity regarding the application of internal control at different levels such as functional, process or entry level is removed with such committee framework approach. Indian Acts must also try to clear, consistent and reliable on internal control measures taken by the companies in their organizations. Certainly, these provisions will increase investors' confidence as well as a sense of protection against misunderstanding. SOX has many such provisions to address non-compliance by the white collar people and their crimes. All in all, it can be concluded from the comparative study of the two acts on the same thrust area of corporate governance, Indian Act, and its provisions are having much wider area of implementation, However it needs timely amendments and refinement in order to cope with changing time and needs, so that it can present a strong sense of corporate governance in India.

\section{References}

ABBOTT, L. J., S. PARKER AND G. F. PETERS 2004. Audit Committee Characteristics and Restatements, Auditing: A Journal of Practice and Theory 23(1), 69-87.

AGRAWAL, A. AND S. CHADHA 2005. Corporate Governance and Accounting Scandals, Journal of Law and Economics 48(2), 371-406.

ARSALIDOU, D. AND WANG, M. 2005. European Business Law Review. Difficulties with Enforcing Western Standards of Corporate Governance in Asia, 2, 329-340.

BAKER, R. C. 2008. Ideological Reactions to Sarbanes-Oxley, Accounting Forum, 32, 2008,

BEASLEY, M. S. 1996. An Empirical Analysis of the Relation Between the Board of Director Composition and Financial Statement Fraud, The Accounting Review 71(4), 443-465.

BERLE, A. A. MEANS, G. C.1932. The Modern Corporation and Private Property. New York: Macmillan. 
Utkarsh Goel, Shailendra Kumar, Kuldeep Singh and Rishi Manrai/Corporate Governance: Indian Perspective with Relation to Sarbanes Oxley Act

BHASIN M. L. 2013. Corporate Accounting Fraud: A Case Study of Satyam Computers Limited, Open Journal of Accounting, 2013, 2, 26-38.

BRATTON, W. W. 2002. Enron and the Dark Side of Shareholder Value, Tulane Law Review, May, 2002.

CARUSO, D. B. 2002. For Years, Rigas Treated Adelphia Like a Family Business, Associated Press Newswires, May 25.

COFFEE JR., J. C. 2003. What Caused Enron?: A Capsule Social and Economic History of the 1990‘s, Columbia Law and Economics Working Paper No. 214, 2003.

DEY. 2008. Corporate Governance and Agency Conflicts. Journal of Accounting Research, Vol. 46, No. 5, 2008, pp. 1143-1181.

ERICKSON, M., M. HANLON AND E. L. MAYDEW 2006. Is There A Link Between Executive Equity Incentives and Accounting Fraud?, Journal of Accounting Research 44(1), 113-143.

FARBER, D. B. 2005. Restoring Trust After Fraud: Does Corporate Governance Matter?, The Accounting Review 80(2), 539-561.

GORDON, J. N. 2002. What Enron means for the management and control of the modern corporation: Some initial reflections, The University of Chicago Law Review, 69(3), 2002, p. 1233-1250.

KINNEY, W. R., Z.-V. PALMROSE AND S. SCHOLZ 2004. Auditor Independence, Non-Audit Services, and Restatements: Was the U.S. Government Right?, Journal of Accounting Research 42(3), 561-588.

NAGARAJAN, G AND KHAJA SHERIFF. J 2012. White Collar Crimes in India, International Journal of Social Science and Inter disciplinary Research, Vol.1 Issue 9, September 2012 p. 114-124.

RUJITHA T R 2012. Challenges to Corporate Governance: Issues and Concerns. International Journal of Marketing, Financial Services \& Management Research, Vol.1 Issue 12, December 2012

SRINIVASAN, S. 2005. Consequences of Financial Reporting Failure for Outside Directors: Evidence from Accounting Restatements and Audit Committee Members, Journal of Accounting Research 43(2), 291-334.

SURAJ A. B., ELANGO S., PAL S., ET.AL. 2012. Corporate Governance \& Independent Directors in India, available at http://tejas.iimb.ac.in/articles/104.php?print=true, accessed on April, 13, 2017 